\title{
Interview
}

\section{Using social media to build a global market - An interview with Leon Wittenberg of Soho - Social Media Consultancy LTD}

\section{Leon Wittenberg}

is the founding partner of the Soho - Social Media Consultancy firm (1969). Leon has been active in the online advertising industry since 1996, and has worked for industry leaders such as Dutch daily newspaper De Telegraaf, 24/7 RealMedia, SuperTracks, AdPepper Media, LaComunidad (GroupMMPP), and the first global social media agency, SocialMedia8.

ABSTRACT Michael Moon had a conversation with Leon Wittenberg about his progressing role in the Online Advertising Industry as a Social Media Strategy specialist. They talked about how the traditional advertising market is rapidly being influenced by the progressive growth of so-called 'social media.'

Journal of Digital Asset Management (2009) 5, 274-285. doi:10.1057/dam.2009.20

Keywords: client engagement; social media marketing; viral marketing; brand ambassadors; social media strategy

MM: We're here with Leon Wittenberg of Soho.

Leon - if you would - give us a little bit of your personal and professional background. LW: Okay. Well, my name is Leon Wittenberg. I currently work for Soho - Social Media Consultancy, an international consultancy firm, addressing social media marketing, viral marketing and client engagement strategies, for international brands.

Basically, I started in the online advertising market in 1995, when I began working for a Dutch newspaper named 'De Telegraaf.' At that time, online advertising was just starting in the Dutch market.

This newspaper made an HTML version of the newspaper. It was simple, flat principle -

Correspondence: Leon Wittenberg Soho - Social Media Consultancy LTD, Villa Marien-Staete - Plantsoen Zuid, Stadsring 246 3811 HS Amersfoort, The Netherlands E-mail: Info@ soho-consultancy.com they put certain sections from their editorial department onto the web.

From the beginning, De Telegraaf asked me to look into ways of how to exploit that. Of course, we started with putting buttons and banners all over the place - until there were so many spaces occupied that it slowly started to resemble a Christmas tree.
Everybody called it the 'Christmas Tree,' because there was so much advertising on it. That was because it really was in the Web 1.0 era, where websites basically were seen as digital versions of the newspaper.

In that period - from 1996 until 1999 - I had the opportunity to talk to all of the large customers of the newspaper - the advertisers and to explore with them how they perceived the Internet and how they felt about Internet advertising. That, quickly, gave me some expertize in the Dutch online advertising market.

In 1999, that led us to a company called 'Real Media.' They approached us to use their technology for streaming the advertising. They had a system called 'Open Adstream.'

De Telegraaf integrated that system into the website. During that process, I became very familiar with Real Media, as a company. After a while, I was approached to become their managing director in the Benelux market.

So I left De Telegraaf and became the managing director for Real Media, starting a local network of Dutch websites. And to exploit 
the network of international sites in the local

Dutch market.

That gave me the opportunity to, again, early on in the online advertising market, talk with a lot of website owners who had all kinds of different ideas how to make money out of a website. Concurrently, the large international, successful websites that already were making money out of advertising business - and were in the network of Real Media - were offered to local Dutch companies, who wanted to do international online advertising.

I did that for a couple of years, and then was asked again by De Telegraaf to start a new project. This project was the 'Woonkrant' project. This was a website for the Dutch real estate market. It was a really big part of the print market of the Dutch Telegraph. They were losing market share really rapidly in 2001 , to all kinds of new players in the market, starting Internet sites showing vacant houses.

This was also a really interesting period, because I was interested in knowing how Internet could change the behavior of people who were looking for a home quickly. In the matter of only a few years, people didn't use the newspaper any more, but solely used the Internet to look for new houses.

That meant - for a company like De Telegraaf that the real estate market where they were market leader for probably 30 or 40 years was changing rapidly.

It was a very challenging period to use Internet technology and the relationship with real estate agents in the Dutch market, to create a turnaround situation. In a period of almost 3 years, we created this Dutch website, with the brand name Woonkrant - the same brand name as the newspaper edition.

We came up with an integrated model, where real estate agents and advertisers could use the Internet site and the print section in one bite - at one (digital) front office. One contact person dealt with the whole advertising business of this real estate agent.

At that time, we were one of the first multimedia departments of a big publisher in the Dutch market, who was offering Internet and print in one proposition.

We had a back-office system where real estate agents could log in. They could advertise on the site, but they could also - with the same data - advertise in the newspaper. It became really easy, via a media management application, for this real estate agent to publish their advertising at De Telegraaf. And it didn't matter any more if it was the newspaper or the Internet site - because it was an integrated model.

That was exciting and successful. We made a lot of revenue out of it. And we showed the Dutch market pretty early that it was really possible to build this killer application, where you could conquer a market and integrate a traditional advertising business with new media.

Of course, De Telegraaf did the same trick with the advertising business for second-hand cars. That was also a really big market. They had the same problem. They were losing market share.

After a period of almost 6 years, working for De Telegraaf on all kinds of online advertising business models, it was time to start something else. I made a shift to the entertainment business. More specifically, I started working for a record company.

This record company had the challenge that they had a number of successful artists that were trying to make profit out of the traditional record company business models. Right at the time when social media was coming up.

This was around 2004. We were one of the first record companies here in the Dutch market that discovered the power of social media, mainly via MySpace and YouTube for the marketing and sales of artists.

Specifically, it was interesting to see how the globalization of marketing through social media became one of the biggest power themes in this whole development of social media.

It appeared to me - at that time - that the way social media works, it's similar to how artists are building fan bases. The behavior of fans going out and discovering new bands and new music - creating a critical mass of supporters - then by word-of-mouth advertising, this fan base becomes bigger and bigger and bigger.

There is a parallel in how successful brands operate within social media. You can directly compare this with how artists create fan bases, and how this whole word-of-mouth principle works in the entertainment business. 
After a few years - and after launching a few local artists through platforms like MySpace, internationally - we saw instant success with the Dutch turntablelism/crossover band 'C-Mon \& Kypski' (www.c-monandkypski.nl). They were invited to perform at the South-by-Southwest festival in Austin - which is one of the larger music festivals in the US.

That was 'sort of' the start of their whole international career. A big factor of their success was the social media presence that organically started to shape around their appearance on YouTube, Hyves (local Dutch social network), Facebook and MySpace.

That made me think, 'Okay - How will this whole social media mechanism influence the way advertisers are now going to make use of these huge communities of people sharing content?'

This whole learning curve, from the record company and my background in online advertising, led to a new era in my career. I started working for LaComunidad (a GroupM/ WPP company) in 2008, creating SocialMedia8, the first global social media-marketing agency.

There seem to be several aspects of marketing integrated in a new sort of specialty, called 'Social Media Marketing.' There, you need knowledge about PR and how PR is working. But you also need to know how the word-tomouth marketing is working. How, in a digital age, 'push' advertising is not working, any more.

You need to have an understanding of what content is appealing and interesting enough to be distributed through viral mechanisms.

That whole combination was basically in my background. We made SocialMedia8 pretty much a success within 6 months. Because we formed a team of people who all had their backgrounds in Public Relations (PR), in research or in online advertising. We combined those disciplines in the social media agency.

We found out that there is a huge need from brands, but also from creative and media agencies to learn and understand how social media is working.

MM: This might be a good time to summarize how media planning agencies have traditionally worked with print and broadcast advertisers. Could you compare and contrast those traditional channels with how social media agencies pick up where the traditional media planning agencies leave off?

LW: I think the main issue here is, all of the traditional media agencies are thinking in terms of campaigns. The campaigns have starting and end points, which probably - most of the time are periods of 4-6 weeks.

Before a campaign is launched, they create a media plan, which has a certain goal - and a certain number of people they need to literally push from A to B. When the campaign starts, their work is finished, basically - until the campaign is finished. Then they report on the end result to the advertiser.

MM: Leon, this gets to what I call the 'Marketing Procedural.' A traditional marketing campaign usually starts off with some new insight - often derived from customer research or customer requirements. Or some new technology that comes along.

That then leads into an overall marketing strategy. 'How do we allocate our resources for maximum advantage?' Out of that strategic plan, you get a marketing plan, by which you onboard all the members of your marketing team - in terms of what they need to accomplish. So there's some integration and synergy and consistency of message and voice across multiple channels, such as in-store promotions, online advertising, guerilla marketing, broadcast and print ads and so on.

Then, as it comes time to start building, you then do a creative brief - a subset of the overall marketing brief.

The advertising agency or direct response firm or PR firm goes off and creates content.

That then goes through this iterative process of editing, until such time that we finalize an ad or direct-mail piece that's consistent with the overall marketing strategy.

Now into this thing, we're probably anywhere from 6 to 11 weeks from the original insight. At that point, for some media measured media - I go to a media-planning firm. They say, 'Okay. Let's aggregate our insertion orders in a way that we can maximize volume discounts,' and so on.

Usually, the media-planning agency has its own set of analytic data, in terms of audiences, reach and number of impressions. Is this so far on track with your experience?

LW: Absolutely. 
MM: So then the media agency has relationships with the advertisers - both traditional print advertisers and, increasingly, online advertisers - through these ad networks and so on, and places the media. Then, as you say, they've done their work and they're waiting for a new crop of ads to come through by which to plan and place.

LW: Exactly.

MM: That linear marketing procedural tends to be very deterministic and structured. It flows one way.

I think the point you were about to make is that social media planning is inherently not linear. It's circular.

LW: Yes. Absolutely. It only starts when you start to do something. The big difference is, as you mentioned for creating this ad campaign, the basis is often some sort of insight that they found out through marketing research or some other thing.

If you look at the typical social media campaign, it's often conversational tracking that is the basis of this insight.

MM: Tell me more about what you mean by conversational tracking.

LW: What we see now is that when advertisers start to look at conversations on the Internet if you examine those conversations - people who are talking on a blog about a certain company or product or service - it shows that often these conversations have insights in them that are extremely valuable for brands or advertisers.

MM: So this has led to almost a boutique industry of social media monitoring.

LW: Yes. Exactly.

MM: There, we have specialized tools and services that crawl through hundreds of thousands or millions of blogs and forums and social networking pages. Scanning on particular keywords and phrases, as they relate to a market category or a brand or a position within a category.

LW: Exactly. Absolutely. Yes.

Today we have this technology to look at huge amounts of data. The technology today is - at this level - that on the surface of all of these data, you start to recognize insights that are extremely helpful in creating the conversation instead of a one-way advertisement/campaign/ shouting, 'Buy me, buy me, buy me!'
MM: So in effect, you're saying that the social media monitoring - where we're tracking conversations about customer requirements and brand use - this leads to a response to a known customer requirement. As opposed to the typical marketing procedural - which is not necessarily in direct response to anything - but it hopes to elicit a response.

LW: Exactly. Yes.

MM: So you were saying that social media planning begins in conversation tracking.

LW: Yes. Often. Well, it depends on what level the advertiser is starting his social media program. But in an ideal world, a social media campaign would start with a social assessment. So, a brand assessment of, "What is the position within social media of this particular brand or product or service?'

MM: What are some of the things that come out of a brand assessment?

LW: For example, a very clear insight could be that you - as a brand - do not have a position inside social media. Said otherwise, people are not talking about you. Or they're not talking about your product. Those are the really quick assessments.

MM: Those are easy, because the thundering sound of silence becomes overwhelmingly self-evident.

LW: Exactly.

But, for example, if you do conversational tracking for - let's say - a bank in this era. Let's say it's a corporate bank. A pretty big one that had a lot of trouble in the last 6 months. You can imagine that the numbers of conversations you will find about this financial institute are so overwhelming and the amount of data is so great that it's even impossible to analyze it.

There, you need technology to make some sort of footprint of what the conversations are about.

We basically talk about conversations and we talk about who is saying it - and we're talking about sentiment. To make it a little bit easier, we have three categories of sentiment - the negative sentiment, the neutral sentiment and the positive sentiment.

In my opinion, a social media campaign is often designed to shift sentiment - or to create sentiment, if there is none.

By starting with a brand assessment determining what the position is of a brand, 
product or service within social media - that's the first step. The second step is that you start to examine those conversations about topics, authors and how influential some of these conversations are.

Out of that, you create insights that are most of the time - really valuable. The qualities of those insights is a lot better than what marketers are used to. Of course, a decade ago, brands were also doing this kind of research. But they did it in a confined space, with 10 people asking them, 'Do you like my ad?'

If eight of those 10 people said, 'Yes,' then all the marketers were happy - because they had a positive review of their advertisement. Today, it's completely different.

Even if you start an online display advertising campaign, and you are a brand with plenty of brand recognition, you will find that people will start to talk about your advertising. If you do a new TV spot, you'll find that the next morning, people will talk about it.

Those insights, basically, the response of people within social media on what you are doing as a company in terms of marketing, PR, communications - that brings really, really relevant information to the table, information on how people perceive your communications.

This new interest of brands in all those conversations is really the first step in creating a dialog instead of creating an advertising campaign.

MM: Could you take us through an actual campaign or program from the initial set of conversations and requirements with a major advertiser, all the way through the seeding of viral videos?

LW: Yes. I can give you an example of this. It's an example of an auto manufacturer in the UK. They were selling family cars.

At that time, they were creating a new online advertising campaign for creating awareness of this new model.

This online campaign had a major goal driving people to the showroom for test drives. They were measuring everything.

By the way, Leon. A fellow in the automobile industry told me that the average cost of getting a buyer onto a showroom floor is US\$475.00.

LW: Wow. Yes. I can imagine.
MM: Was that the car manufacturer's goal? To use online advertising and social media to drive showroom floor traffic?

LW: It was the online advertising campaign that was supposed to do that. We merely did conversational tracking as an experiment, at that time, to see if there would be any conversations involved by this advertising campaign. That was the general idea.

We did conversational tracking to track all the conversations about the brand, and about this new model. Very early in the campaign, we found that the people perceived the campaign very positively. They really liked the car. It was a really nice model.

But there were two major issues that had a bit of negative sentiment. It was around this whole interdiction of room space, I believe, in the back of the car. The second thing was that the car was being perceived as too expensive.

In all communications, they'd decided not to communicate the price. They were focusing on the luxury and appearance, and they did nothing with price.

Early on in the campaign, they already could see that the results were not satisfactory. In terms of advantage, they were reaching their goals. But in terms of traffic to the showrooms, they didn't.

So we came up with a report pretty quickly. We analyzed and we came to the conclusion, 'Change your strategy into a pricing strategy.' There's a lot of confusion about the price.

Actually, the client took this advice. They changed the strategy, and suddenly the whole campaign turned around - and they were able to reach their targets.

For me, it was the first situation where we actually really could gain consumer out of a conversational tracking program during a live campaign. And in the middle of the campaign, we could change the strategy because of the insights that we gained.

MM: That does a great job of summarizing social media monitoring as a way of driving new insights into a mid-course correction on a linear marketing procedural campaign.

There were a couple of themes that I'd like you to develop. One is the theme of video sharing. How video sharing has become a really very significant part of the overall conversations that customers are having - as opposed to 
simply posting comments on a blog or in a forum.

LW: First of all, the fun thing of this whole business is that - as you know - buying Gross Rating Point (GRPs) - putting your commercial on television - is one of the most expensive media types. But it's also still one of the most effective ones. That's why a lot of advertisers are still using TV commercials to achieve their marketing goals.

In the early stage of social media marketing when we started - a lot of those advertisers approached us with a traditional TV commercial ad. They asked us, 'Can you put this on the Internet? Can you put it on YouTube? What is the cost for that?'

We told them, 'Well, the cost for that is nothing. You only pay the people who will put it online for you. But YouTube will charge you nothing for putting your TV commercial on YouTube.'

In the beginning, they really couldn't believe that they had to pay so much money to put this commercial ad on television, but putting it on the Internet is free.

So that made a lot of brands think that they found the golden egg, in terms of free publicity and free media - just by putting your TV commercial on YouTube. You get a lot of eyeballs for free. That way, the whole idea started about this phenomenon called, 'viral marketing.' You create a very funny commercial and you put it on the Internet. The next day you have 10 million views all over the place, because of YouTube. This is a little bit how the marketers and advertisers perceive viral marketing.

A lot of the advertisers approach Social Media Agencies and say, 'We have this commercial. Can you make it viral for us?' They think that the ability of a social media agency is to make traditional content suitable for viral distribution.

There are only a few brands in the world that can do this. Brands who are really sexy like, for example, Nike or Coca-Cola. They have such brand value that most of their traditional TV commercials become viral overnight. People just love it. They like to share it. That's the whole idea of viral marketing. People who are distributing your commercial for you.

MM: In fact, the essence of viral video is a story that somehow connects not only with me, but it connects with me in such a way that I want to share it.

At this point, the video is no longer an ad, but it's a way of communicating something or sharing something with another person.

LW: Absolutely.

MM: It kind of reminds me of the era of mix tapes. Remember that movie 'High Fidelity?' Lovers creating mix tapes - compilations of songs - that really expressed the dimensions of their relationships.

It seems that viral videos pick up where mix tapes left off. It's simply an easier and more convenient way of communicating an experience - or sharing an experience - with other people that I know and love. Is that a fair summarization?

LW: It is. Yes. That, and there is a second thing that is really important which relates to what you just described.

It's unbelievable how extremely important it is if you're creating a viral advertisement or viral video, that the content of this video is authentic. If you compare all of the successful viral videos in the market until now, you'll see that there's a commonality. It needs to be really funny or it needs to be violent or really harsh. It's a commonality in terms of authenticity.

It seems that the public has some sort of seventh sense for discovering what is authentic and what is not authentic. Advertisements being created to become viral are usually not authentic, and will usually fail.

That is why - in my opinion - amateurs have created a lot of successful viral videos. Not professional people in the video advertising business. Just people who have an authentic idea and create a video. Those videos are very likely to become viral.

Those videos are, I think, trendy at the moment. They're really suitable for communicating values that are similar to values of a brand. A brand can identify with certain values that are similar in the authentic approach of creating viral content.

By doing this, attaching the two together, they feed each other. That's a really interesting thing.

I remember this story about the creative agencies telling the advertiser that they really need to go to South Africa to create a new TV commercial. The brand says, 'Why do you need 
to go to South Africa?' 'Because in South Africa, we have the best light in the world. For this commercial, we really want to sell your product 100 per cent perfectly. You need to go to South Africa, because there is the best light in the world.'

Then the advertiser says, 'Okay. If it's necessary, you need to do it.' Leading to a really, really expensive production for a commercial.

In the old era, this probably worked. But in the new era, people perceive that as nonauthentic. It will not work.

That's something that is really interesting, because this leaves the large creative agencies with a big problem. The tricks that they used to know to create appealing advertising don't work with viral marketing.

Even stronger, it probably gets a bad reaction from a lot of people.

MM: You'll have to give us the correct spelling of 'viral video' in Dutch. Because as I understand it, it translates into 'Humorous, Horrific or Horny.'

LW: Yes. Correct.

But I think that you should add, 'Authenticity,' to that. If you use those three without authenticity, it will not work. It will backfire, on most occasions. Or people just won't touch it.

MM: It also has to be fresh or innovative. So there's an element of surprise or an element of delight. Something to take you off guard. LW: Often, it looks like somebody who could be you or me is producing it. So you don't need a Hollywood crew in South Africa. You can do it with your own equipment - with your own household stuff. You can create it. MM: In part, that reflects the significantly lower production values of YouTube and MySpace. But the other question I have is, 'Do high production values take away from stories that connect?' Do high-quality production values actually - in the context of social media detract or take away from the authenticity of the piece?

LW: Well, I think you have to put it into two categories. There's still the rule of 'eye candy.' People still like really, really nice things to look at. This still works.

So a really nice, beautiful commercial will still get uptake within social media. Especially if it's a sexy brand like Nike - or something like that.

MM: Or even a gorgeous story like the 'Dove' commercial.

LW: Yes. Absolutely.

Next to that category, you have this category where overproduction will lead to failure.

MM: No, overproduction - is that another way of saying that too many cooks try to check in the kitchen?

LW: Yes.

MM: If I could tease out of this the underlying idea that authenticity - in the context of social media - really entails that there's a creator, an author, a storyteller who has a very distinct point of view.

From this point of view, I create a story. I create content to which other people connect on a visceral, emotional or maybe even tribal level. One of the things that give it this authenticity is that it's not all perfect.

LW: It has rough edges.

MM: But it comes from me.

So the authorship is really very clear. LW: Yes.

By now, a lot of brands have already discovered that if people talk about your brand and, for example, they talk about your brand from a negative perspective - it might be a good idea to interact with those conversations.

So they create WebCare teams or centers. Those people are looking at conversations of that brand all day. Then when something negative pops up, they take out of the drawer a script. This script tells them what to say to those people.

That's a non-authentic conversation. People will notice this and then it will backfire. Creating a WebCare center, with people who have pre-tested scripts of how to respond to conversations on the Internet, will not work. MM: Here I am - a brand manager. What do I do? How do I authentically engage in a conversation with people that are - at best an adversary, that have opposing things to say?

LW: What I meant earlier is that it's not possible for a company to lay down a set of rules about what a WebCare center should do or should not do, in terms of engaging conversations. But assume - as the authenticity of the content of the conversation is scripted - this will backfire. It will 
be like a traditional service department telling you to 'hold.'

MM: So you're saying that in these WebCare centers - if they have them - the individuals in that WebCare center should be able to write and respond in a direct, unscripted way.

LW: Exactly.

MM: That has a much better chance of working.

LW: Yes. They should know the whole story of the company - of the product and of the service. If they know the whole story, they can react authentically to what's going on.

This probably needs a different kind of Public Relations (PR) service manager than we used to have in these departments. Because you really have to think about what you're going to say. You have to be authentic about what you're going to do.

I can imagine for really large, large companies like an energy company, who's getting lots of complaints over time ... It's really hard, how to manage this whole process. How can you be authentic?

MM: It seems to me, Leon, that this goes back to the fundamentals of argumentation and rhetoric.

LW: Yes.

MM: In my understanding and reading, one of the things that really burst forth into the human dimension there was in ancient Greece. It was a notion to be a 'citizen,' in Athens. You not only had to have your household in order, but you had to have your public house in order.

Argumentation and rhetoric entailed the public procedure by which to put your political philosophy - and how best to run the city - in order.

The point of arguing was to apply logic and philosophy to various policies, points or ways of seeing the world - to put that into logical and coherent order - such that you could then present it to others in the public square. Again, in a persuasive way.

In many respects, what you're seeing here Leon, is that for these WebCare centers, essentially, we're training people. We're ultimately training them in the art of argumentation and rhetoric.

LW: Exactly.

MM: How to make a cogent, civil, engaging, persuasive argument. Such that a disgruntled or complaining customer or stakeholder can hear the rationale. They can hear the concern. They feel that they're being listened to.

That then takes it from just simply a conversation to really being something far richer and far deeper than a conversation. Something that coalesces into, 'Hey, we're all in this together. What can I do to help?'

LW: Exactly.

When I started my sales career, I had this sales manager who was always saying to me that a complaint is an opportunity for a new sale. I didn't really understand it in-depth at that time. But I'm beginning to understand it more and more.

If people complain, this is an opportunity to show them that you are authentic in your operations. And that your sole priority is to make life better for your customers.

If that is being done in an authentic way, people are suddenly tolerant. They're much more acceptant than when they are being confronted with procedures. Or by out-of-thebox answers. That's what really frustrates people. MM: Another dimension of this exploration here of authenticity is that the complaining party feels understood and also feels acknowledged for contributing some time and energy to the conversation.

LW: Yes.

I think that the whole thing is, people have been complaining, as long as there have been people. It's in our nature to complain. Specifically, if somebody gives us really bad service - we almost kind of enjoy complaining about it. I think this is something that really goes deep.

In the behavior of people nothing changed. The only thing that changed is that suddenly, all those people now have tools to make complaining about things easier! It used to be that there was a situation with all the women in the village who were washing their clothes and gossiping in the center of the village. They were all complaining, the whole time. But the men didn't know about it, because the men were working in the fields or in the woods.

So for many years, there was no understanding of these complaints. I think it's similar now with social media marketing. Social media tools. They bring all kind of things to the surfaces that were not accessible for marketers or brand managers or CEOs or CMOs up until now. 
MM: So clearly, we're going to need to have the equivalent of marriage counselors for brands and their customers.

LW: Yes. Relationship therapy.

You remember the Microsoft video commercial where the brand and the customer were having a relation problem. They met in the restaurant where they were talking about their relationship - and how it's going down the drain. They don't understand each other any more. It's very famous. You must have seen it.

MM: No. But in the interview, make sure to insert the link.

LW: Yes. I will - definitely. http://www. youtube.com/watch? $\mathrm{v}=\mathrm{D} 3 \mathrm{qltEt}$ l7 $\mathrm{H} 8$.

MM: So Leon, before we run out of time here, I'd like you to take me through how seeding of videos work. Let me set it up this way ...

Here I've got a sports shoe. A hard-court sports shoe that I use to play handball and racquetball inside - on hardwood courts.

LW: Yes.

MM: I've now come to the conclusion that my agency-of-record is constitutionally incapable of developing great viral ads. They're great at doing above the line, traditional broadcast and print ads - but this whole guerilla thing just completely escapes them.

So I come to a guerilla-marketing firm - a social media marketing firm - and I share with you. I'm looking for boys, 14-35 years of age, who are into racquetball, handball and other kinds of hard-court sports. Indoor tennis kinds of things.

I want you to create some compelling viral videos for those. I want you really to build awareness. And more specifically, positive sentiment among the thousands of fanboys out there who blog or write about it.

Just take me through that kind of campaign. LW: Well, first of all, you have to separate the creative process and the planning process. It's basically the creative agency creating the video. And a social media-planning agency consults the brand about the content that they're offering.

So, what could happen - in your example is that a brand, together with the creative agency, uses a social-media agency to gain insights on what could be compelling content or compelling insights.

MM: So a social-media agency does the initial research in terms of, 'What's the conversation, already?' What do people talk about? And perhaps more importantly, what criteria underlie what people are talking about? Therefore, what are the talking points or the stories that might then connect with those people and those particular criteria?

LW: Exactly. That's why I was stating earlier that a good social media campaign should start with gaining insight. Gaining insight for social media is probably done by a brand assessment or conversational tracking program. Where you go in-depth, looking at a certain group of people.

MM: Right. So let's say I've now got the basis for conversation or discussion. I then take those to a creative group to come up with concepts.

Right?

LW: Exactly.

Then the creative agency - together with the advertiser, and, perhaps, the social media agency together, choose the best concepts with the most appealing creative.

MM: Have you ever heard of situations where somebody will fire up a social network environment - and populate this social network with a whole bunch of concepts? Some of them finished - some of them not.

The idea then is that we have all of these creative concepts, and that we put them into a private social network, comprised of various kinds of stakeholders in the category, including target-market customers.

LW: I wish that the brands that I have worked with really understood social media marketing as you mentioned. But, at this point, most of them, they don't.

MM: Fair enough.

So now we've got some viral videos coming. Then what do I do? Both in terms of paid and organic seeding of those?

LW: Well, the organic seeding procedure starts with looking for influentials. That means that it simply takes too much time to try to reach everybody inside of the targetability.

Then we create seeding copy - based on the metadata of the videos. Or the metadata of the text and everything. Then you start creating digital PR, based on the seeding copy that's referring to the video.

Even with good viral content, you need to create awareness. 
For example - YouTube. Every minute, there's another 10 hours of video. It's really hard to find even the good content.

So what a social media agency will do is, they will use their database of influential bloggers that they know - that have relevancy to the content. Then they will ask if those bloggers will post a blog about it - a posting. That's digital PR.

Then those influentials will influence another group of people - early adapters or first movers. That is actually the group that will influence the masses.

We divide them into super-influentials important blogs or big video portals. Big social networks. Next come the influentials - individual bloggers who have a reasonable amount of reach and authority. Then the masses.

MM: We know this, because you have used special software to actually identify how much traffic and unique visitors these particular blogs or influentials are touching on a daily basis.

LW: Yes. And the number of connections that they have.

MM: The number of connections would be links where people have either linked to them or have linked back to them.

Yes.

MM: So in many respects, it's the same kind of algorithm that Google uses?

LW: Yes.

MM: Is that pretty much the end of a viral video program or a guerilla marketing campaign with viral video?

LW: No. What's really important in this whole process is that you have some sort of metric system. For example - Viral Tracker. Tracking your efforts both on the side of PR, or uptake of blog or those things. And the number of video views that are being created by the uptake of the blog postings.

Based on the output of a viral tracking system, you can determine where the content is doing better, and where it is not.

This also, for example, has to do with cultural differences. Some content does it really well in South America, but it will not work at all in Scandinavia.

MM: Another dimension of a viral or guerilla marketing campaign with social media is that the lifespan or the life cycle of a social media program tends to be much longer than the lifespan of a traditional advertising campaign. Can you speak to that?

LW: Yes. A successful viral campaign can run 6, 12, 18 or 24 months. The longer the reach goes on, the lower the cost-per-contact. That's really the interesting mechanism of a successful viral campaign. The more success, the lower the cost.

MM: In the analysis of traditional media benchmarks - in terms of reach - how do moderately successful social media marketing programs measure up to traditional direct response or traditional advertising?

LW: It depends on the success of the creative. Global social media marketing - can be a very expensive thing if it's not successful. It's on an hourly basis. So social media marketing tends to be expensive if it's not successful.

On the other hand, if you are successful with this social media marketing program, and you hit some sort of viral effect, and people start distributing your content for free, then the more views you get, the lower the cost-per-contact will be.

I've seen campaigns anywhere between $€ 0.01$ and 0.25 per contact cost. If I talk about contact cost, I'm talking about user engagement. It's not to be confused with a click price or something like that. But the content has already been consumed.

For example, to make it clearer, we know of big global campaigns for big retail brands. They do these global campaigns. We've worked with different techniques. We've used organic seeding techniques. And we've used paid seeding techniques.

Of course, paid seeding looks a lot like advertising.

MM: And how does paid seeding work?

LW: You pay influentials to post your content. I don't know if you have heard of Google Video Network, but it's running now in Europe, really successfully. Why? Because they've created this really large network of all kinds of sites that are part of the Google Ad Network. They all use Ad-Sense, for example.

But they also now have created these paid positions in this network. In this display position, you can serve a video - like it is a television advertisement. But people still have to click on it before they see the video. 
The funny thing is that Google gives this away for free. You don't have to pay for the video view in the Google Video Network. You pay for the click that comes behind it. In one sentence, that shows how social media marketing is still being received as another form of advertising. Which it's not.

The value of social media marketing is not the click behind the video view. I don't care about the click, at all. I only care about the fact that people have seen the video. What they do afterwards, I don't. The click is something else.

It's nice if they would click on a link after they have seen a video, but it's basically more or less not the goal of a social media campaign. The campaign is about creating awareness and engagement by showing this video.

MM: So, how does effective social media marketing parallel the lessons a brand might learn from studying how fans build fan bases? LW: The most important learning point - for me - I can put into two sentences. The first is that a beginning artist or a band, or somebody who is artistically active on a stage and wants to become famous must realize that you win your audience one by one.

You have to be willing to start doing some one-on-one communications. Forget about mass communication. It doesn't work. You have to communicate to individuals.

By doing that, and by using the mechanisms of word-of-mouth marketing and viral distribution, slowly your fan base will grow.

The second learning is that if you do this in the correct way, you will create friends for life. Because fans of pop artists are very loyal.

It seems to me that if you look at the big global brands that are successful today in social media marketing and viral marketing, those brands look like rock artists. There is a similarity there.

MM: So what goes into making a really great artist?

LW: For me, it's authenticity. But you know me. I'm an authenticity freak.

MM: Clearly, authenticity plays a very large role. But it also seems to me that an artist is someone who has created a vision regardless of whether you like it or not.

LW: Exactly. Yes.

It's a 'pull' mechanism instead of a 'push' mechanism. It's really important that you say this. The end conclusion of, 'What's the difference between advertising and social media marketing?' It's basically 'Push (advertising),' and 'Pull (social media marketing).'

MM: We might find another parallel in something very popular here in North America. I'm not quite sure how popular it is in Europe and specifically, the Netherlands. That's the notion of the stand-up comedian.

LW: Yes.

MM: He stands up on a stage and starts talking. No band. No props. He tells stories that immediately have to engage, or it's a very long night.

LW: True.

MM: This reminds me of an interview I heard with one of the grande dames of comedy $-\mathrm{a}$ woman named Phyllis Diller. Again, probably not well known in Europe. But iconic, here in North America.

She talked about breaking into the comedy business back in the 1950s and 1960s. She said, 'You know, you have to deliver a joke about 75 times before you've really gotten the pace and the timbre and the posture and the facial expression timing'.

LW: Yes.

MM: She said that probably takes about five years to develop about $20 \mathrm{~min}$ of really authentic material.

LW: Wow. I believe this. Yes.

MM: Who knows if it takes five years to develop a social media marketing program? But the underlying idea is that failure is not the end. It's just the prelude to new insights as far as how to do it better. How to engage more effectively. Winning fans, one fan at a time. LW: Exactly.

This is completely the opposite of masscommunication. In that perspective, the traditional marketers are almost like spoiled children. It's really interesting to learn that this will no longer work in the future.

MM: As we bring that back to another theme that we were developing around the marketing procedural, speaking to your point of 'spoiled children with piles of money ...'

This constitutes the idea of bringing customer engagement into a strategic marketing program, really a square peg in the round hole of most planning.

To your point, effective social media marketing starts with listening. Actually, it starts 
with monitoring. You have to have the tools in place to monitor.

Then you have to listen. Then you have to understand what they're telling you. Then you have to formulate. 'What's our best response to what we're now understanding of what people say?'

LW: Yes.

MM: Then, 'Let's go try something.'

So, rather than getting it perfect - much in the manner that Google loves, the idea is to ship fast - ship often - get it out there. Listen and correct.

So you could say that the traditional marketing program entailed shipping a complete software suite. In the new world, every campaign is a beta.

LW: Exactly. Yes.

You will find new learnings in the next campaign.

MM: So then what we're really talking about is having multichannel analytics - being far more important in terms of finding your way through the myriad conversations that make up a noisy market.
Once we've understood and developed the listening tools and analytics by which to understand, then it's the ability to execute in a matter of hours or days, based on what we've learned - as opposed to weeks or months, which is the typical marketing response.

LW: Correct. Yes.

MM: So the planning of strategic marketing will continue to undergo a radical transformation. Becoming much more non-linear, circular, almost opportunistic as new insights come, and our ability to execute against those insights ... LW: Yes. It's like the certainty of a hit. You create the album of 13 hard-labored songs, and probably only one of them will become a hit. But it doesn't matter, because the hit is the carrier for the other 11 songs that you've created.

MM: And more importantly, gets people to come down the stadium, to hear you play it again live.

LW: Exactly. That's engagement.

MM: Yes.

This sounds like a great place to conclude our conversation. Leon - thank you so much. LW: It was really fun talking with you again. 